Çukurova Üniversitesi Mühendislik Mimarlık Fakültesi Dergisi, 30(1), 95-104 ss., Haziran 2015

Çukurova University Journal of the Faculty of Engineering and Architecture, 30(1), pp. 95-104, June 2015

\title{
Şantiye Şeflerinin Sorumlulukları
}

\author{
M. Alptekin HERGÜNER ${ }^{1}$, Emel LAPTALI ORAL ${ }^{* 1}$ \\ ${ }^{1}$ Çukurova Üniversitesi, Mühendislik Mimarlık Fakültesi, İnşaat Mühendisliği, Adana
}

Geliş tarihi: 27.02.2015

Kabul tarihi: 25.06.2015

\section{Özet}

Ülkemizde yeni mezun mühendis/mimarların yaptıkları işin yetki sınırları/hukuki sorumlulukları hakkında yeterli derecede bilgi sahibi olmadan, düşük ücret ve yüksek sorumluluklarla şantiye şefi olarak çalıştırıldığı bilinen bir gerçektir.

$\mathrm{Bu}$ çalışmanın amacı şantiye şefi olarak bilfiil çalışan teknik elemanların sorumlulukları ile ilgili mevzuat hakkında bilgi/farkındalık seviyesini belirlemek ve ilgili mevzuatı genel başlıklar altında toplamak olmuştur. Bu amaç doğrultusunda bir anket çalışması yapılmış, anket sonuçları kapsamında; şantiye şeflerinin ilgili mevzuata ne düzeyde hâkim olduğu, ne oranda uygulandığı ve bunun inşaat sahasına yansımaları incelenmiş̧ir.

Anahtar Kelimeler: İnşaat sektörü, Şantiye şefi, Yapı güvenliği, İş güvenliği

\section{Responsibilities of Site Managers}

\begin{abstract}
It is a well known fact that new graduates of civil engineers/architects are employed as site managers with low fees/high responsibilities without having any idea about their responsibilities within the frame of the related legislations.

The aim of this study is to determine the awareness and knowledge level of site managers related with their responsibilities and to summarize related legislations under main headings of site manager's responsibilities. A questionnaire survey was undertaken in order to achieve the aim of the research.
\end{abstract}

Keywords: Construction sector, Site manager, Construction safety, Work safety

\footnotetext{
* Yazışmaların yapılacağı yazar: Emel LAPTALI ORAL, Mühendislik Mimarlık Fakültesi, Inş̧aat Mühendisliği Bölümü, Adana.eoral@cu.edu.tr
} 


\section{GíRIȘ}

Şantiye şefi "İnşaa faaliyetini müteahhit adına yürüten, personelin ya da taşeronların sevk ve idaresini sağlayan, iş güvenliğinin sağlanması için gerekli tedbirlerin alınıp alınmadığını denetleyen, yapının fen ve tekniğe, ruhsat ve projesine uygun olarak inşa edilmesini sağlamakla yükümlü olan gerçek kişidir" [1].

Şantiye şefliği tanımı ayrıca; 05.02.2008 tarih ve 26778 sayıl1 Resmi Gazetede yayımlanan [2], Yap1 Denetimi Uygulama Yönetmeliği'nin 9. maddesinin ikinci fikrasında yapılmaktadır. $\mathrm{Bu}$ tanıma göre; "Yapım işleri yürütülen şantiyede, mühendis veya mimar diplomasına sahip olmak üzere bir şantiye şefinin bulundurulması mecburidir...". Bu tanımda geçen 'mühendis' ifadesi elektrik, makine ve inşaat mühendislerini kapsamakta, konu ile ilgili ek bir açıklama Çevre ve Şehircilik Bakanlığı'nın 1 Ağustos 2013 tarihli, 6581 Sayılı 2013/24 no'lu Genelgesi [3] ile yapılmaktadır. Genelgeye göre ilgili idareler tarafından şantiye şefliği görevi verilirken, görevlendirilecek personelin, yapım işinin gerektirdiği ve imalatın niteliğine uygun meslek grubundan olması gerekmektedir.

Şantiye şefi olma şartları 2010 tarihinde Resmi Gazete'de yayımlanan "Yap1 Müteahhitlerinin Kayıtları ile Şantiye Şefleri ve Yetki Belgeli Ustalar Hakkında Yönetmelik" [1] ile düzenlenmiștir. $\mathrm{Bu}$ yönetmeliğin 10. Maddesi kapsamında şantiye şefinin, yapım işinin uzmanlık alanına uygun olmak üzere mimar, mühendis veya bunlara ilişkin teknik öğretmen veya tekniker olması şartı aranmaktadır. Fakat konu ile ilgili TMMOB tarafindan dava açılmış ve Danıştay kararı ile teknik öğretmen ve teknikerlerin şantiye şefi olma yetkileri kaldırılmıştır.

Şantiye Şefinin görev, yetki ve sorumlulukları 3194 sayılı İmar Kanunu [4] Madde 28, Yapı Müteahhitlerinin Kayıtları ile Şantiye Şefleri ve Yetki Belgeli Ustalar Hakkında Yönetmelik [1] Madde:10/6, 10/7, 10/8, 10/11 ve 6331, Yap1 Denetimi Uygulama Yönetmeliği [2] Madde: 9/3, 9/5, 9/6, İş Sağlı̆̆ı ve Güvenliği Kanunu [5]
Madde: 3/2 de belirtilmektedir. İlgili maddeler aşağıda verilmiştir.

Şantiye şeflerinin yetki sınırları;

(1) Şantiye şefi, görev yaptığ 1 ilin sınırları dışında başka bir ilde görev üstlenemez ve yönetmelikte belirtilen toplam $\mathrm{m}^{2}$ sinırları aşılmamak kaydıyla aynı anda en fazla beş ayrı yapım işinin şantiye şefliğini üstlenebilir [1].

(2) Mimar veya mühendis unvanlı şantiye şeflerinin aynı anda üstlenebileceği işlerin toplamı $30.000 \mathrm{~m}^{2}$ yi geçemez. Ancak yapım işinin tek ruhsata bağlı veya toplu yap1 niteliğinde olması halinde $30.000 \mathrm{~m}^{2}$ yi geçmeme şartı aranmaz [1].

(3) Kamu binaları, bodrum hariç 2 kattan yüksek olmayan yapılar, $500 \mathrm{~m}^{2}$ inşaat alanından daha düşük inşaat alanına sahip yerlerde şantiye şefi bulundurulması zorunlu değildir [1].

Şantiye şeflerinin yapı ruhsatı alınması ve yapının ruhsata uygun şekilde inşaa edilmesi ile ilgili sorumluluklar1;

(1) Yapı müteahhidi ve şantiye şefi; yapıyı, tesisatı ve malzemeleriyle birlikte bu Kanuna, ilgili diğer mevzuata, uygulama imar planına, ruhsata, ruhsat eki etüt ve projelere, standartlara ve teknik şartnamelere uygun olarak inşa etmek, neden olduğu mevzuata aykırılı̆̆ 1 gidermek mecburiyetindedir. Yap1 müteahhidi ve şantiye şefi, ilgili fenni mesullerin denetimi olmaksızın inşaat ve tesisatlarına ilişkin yapım işlerini sürdüremez, inşaat ve tesisat işlerinde yetki belgesi olmayan usta çalıştıramaz [2].

(2) Şantiye şefi, yapı müteahhidi adına, yapım işinin ruhsata ve ruhsat eki etüt ve projelere uygun olarak gerçekleştirilebilmesi için gerekli olan inşaat ve iş organizasyonunu sağlamak, mevzuatın öngördüğü her türlü tedbiri almak, uygulamak ve uygulatmakla sorumludur[1].

(3) Şantiye şefi görev aldığ ruhsatı ve yapı kullanma izin belgesini imzalamakla yükümlüdür [1].

(4) Şantiye şefi; yapıyı ilgili mevzuat hükümlerine, ruhsata ve eki projelere, denetçi mimar ve mühendis ile kontrol ve yardımcı kontrol elemanlarının talimatlarına uygun olarak inşa 
ettirmek, yapı denetimi sirasında bizzat hazır bulunarak, denetimin uygun şartlar altında yapılmasını sağlamak, yapı denetleme defterini şantiyede muhafaza etmek, bu defterin ilgili bölümünü ve yap1 denetim kuruluşunca düzenlenen diğer tutanak ile belgeleri imzalamakla yükümlüdür [2].

Şantiye şeflerinin iş sağlığı ve güvenliği ile ilgili sorumlulukları;

(1) İşveren adına hareket eden, işin ve işyerinin yönetiminde görev alan işveren vekilleri, İş Sağlığı ve Güvenliği Kanunu'nun uygulanması bakımından işveren sayılır [4].

(2) Şantiye şefi görev aldığ1 yapım işinde iş sağlı̆̆ ve güvenliği ile ilgili eksiklik ve kusurları, öneri ve önlemleri belirlemek, yap1 müteahhidine rapor etmek ve şantiyede görev alan ilgili kişilere bildirmekle yükümlüdür. Raporda yer alan hususların yerine getirilmemesinden yapı müteahhidi sorumludur [1].

(3) Şantiye şefleri $1 / 1 / 2012$ tarihinden $1 / 1 / 2020$ tarihine kadar 4857 sayılı İş Kanununa uygun iş güvenliği uzmanlığı belgesi alması zorunludur [1].

Şantiye şeflerinin yapım işleri ile ilgili sorumlulukları;

(1) Yap1 denetim kuruluşları, denetçi mimar ve mühendisler, proje müellifleri, laboratuar görevlileri ve yap1 müteahhidi ile birlikte yapının ruhsat ve eklerine, fen, sanat ve sağlık kurallarına aykırı, eksik, hatalı ve kusurlu yapılmış olması nedeniyle ortaya çıkan yapı hasarından dolayı yapı sahibi ve ilgili idareye karşı, kusurları oranında sorumludurlar. $\mathrm{Bu}$ sorumluluğun süresi; yap1 kullanma izninin alındığı tarihten itibaren, yapının taşıyıcı sisteminden dolayı on beş yıl, taşıyıcı olmayan diğer kısımlarda ise iki yıldır [6].

(2) Yap1 müteahhidi ve onu temsilen görevlendirilen şantiye şefi, yapım işlerindeki kusurlardan dolayı müteselsilen sorumludur [4].

(3) Yap1 müteahhidi veya onu temsilen görevlendirilen şantiye şefi, inşaatta herhangi bir imalata başlamadan en az bir gün önce, yapılacak imalatı yapı denetim kuruluşuna haber vermek zorundadır. Aksi takdirde, işin denetimsiz ilerlemesinden doğabilecek her türlü sorumluluk yapı müteahhidine ve onu temsilen görevlendirilen şantiye şefine aittir [4].

(4) Şantiye şefi, inşaat ve tesisat işlerinde yetki belgeli usta çalıştırılmasından sorumludur [1].

Şantiye Şeflerinin Karşılaşabilecekleri Cezai

Durumlar;

Şantiye şeflerinin yukarıda özetlenen mevzuat kapsamında sorumluluklarını yerine getirmemeleri durumunda karşı karşıya kalabilecekleri cezai durumlar aşağıdaki başlıklar altında özetlenebilir;

(1) Yap1 ruhsatı alınmaması veya yapının ruhsata uygun şekilde inşa edilmemesi sonucunda ortaya çıkabilecek cezai durumlar;

- Şantiye şeflerinin yapı ruhsatı alınması ve ruhsata uygun yapı inşa edilmesi konusundaki sorumlulukları yukarıdaki bölümde sıralandığı gibi üç farklı mevzuatla $[1,3,4]$ düzenlenmiştir. $\mathrm{Bu}$ konuda sorumlulukların yerine getirilmemesi konusu ise Türk Ceza Kanunu'nun 184. Maddesi [7] ile ele alınmaktadır. $\mathrm{Bu}$ maddede yap1 ruhsatı almadan veya ruhsata aykırı olarak bina yapan veya yaptıran kişinin, bir yıldan beş yıla kadar hapis cezası ile cezalandırılacağı belirtilmektedir. Aynı maddenin başka bir bendinde kişinin ruhsatsız veya ruhsata aykırı yaptığı veya yaptırdığ ruhsatına uygun hale getirmesi durumunda kendisine kamu davası açılmayacağı, açılmış kamu davasının da düşeceği ve mahkûm olunan cezaların kaldırılacağı belirtilmektedir.

(2) Şantiye Şeflerinin Yapım İşleri ile ilgili Sorumluluklarını Yerine Getirmemeleri Sonucunda Ortaya Çıkabilecek Cezai Durumlar

- Yukarıdaki bölümde belirtildiği gibi Yapı Denetim Yönetmeliği yapım işlerinden kaynaklı kusurlardan dolayı müteahhit ve şantiye şefini müteselsilen sorumlu tutmaktadır. Bu durumda tüzel bir kişilik olan müteahhit firma maddi zararlardan şirket malı sınırları içinde sorumlu olmakta, ayrıca bazı durumlarda tüzel kişiliği ortadan kalkmış bile 
olabilmektedir. Bu nedenle yapı sahibi maddi zararının karşılanması için birey olarak erişebileceği şantiye şefine dava açmakta şantiye şefi de müteahhide ayrıca bir dava açıp zararını karşılamaya çalışmaktadır.

(3) Şantiye Şeflerinin İş Sağlığı ve Güvenliği ile ilgili Sorumluluklarını Yerine Getirmemeleri Sonucunda Ortaya Çıkabilecek Cezai Durumlar

- 6331 sayılı İş Sağlığı ve Güvenliği Kanunu şantiye şefini iş sağlığı ve güvenliği açısında işveren kabul etmektedir. $\mathrm{Bu}$ durum şantiye şefini kanunun ve ilgili mevzuatın tüm gerekliliklerinden sorumlu tutmakta, uygulamada herhangi bir aksaklık veya eksiklik belirlediği zaman bunları müteahhide ve işçilere yazılı olarak belirtme zorunluluğu getirmektedir. Aksi takdirde herhangi bir kaza anında şantiye şefi kazanın sonucuna göre Türk Ceza Kanunu [7] hükümlerine göre taksirle adam yaralama/öldürme suçundan yargılanıp, ek olarak kazazedenin ailesine maddi/manevi tazminat ödemek zorunda kalabilmektedir.

\section{MATERYAL VE METOT}

Bu çalışma kapsamında, şantiye şefi olarak çalışan mimar veya mühendislerin; iş sağlığı güvenliği, yapım işleri ve yapı ruhsatı alınması ile ilgili sorumlulukları, yetki sınırları, karşılaşabilecekleri cezai durumlar hakkındaki farkındalık düzeyini ölçmek amaciyla 10 sorudan oluşan bir anket hazırlanmış ve www.surveymonkey.com sitesi aracılığıyla, Çukurova Bölgesinde çalışma hayatını sürdüren şantiye şeflerine, ulaştırılmıştır. Toplamda 32 geri dönüşün gerçekleştiği anketimizde, katılımcılar tarafindan verilen cevaplar istatiksel olarak değerlendirilmiş ve Microsoft Excel 2010 programında oluşturulan çizelgeler aracılığıyla görsel çıktılar her soru için ayrı ayrı oluşturulmuştur.

\section{ARASTTIRMA BULGULARI VE TARTIŞMA}

Soru-1) Mezun olduğunuz Lisans bölümü hangisidir? Şantiye Şefi olarak sektörde çalışma süreniz kaç yıldır?
Çizelge 1. Katılımcıların mesleki dağılımları ve tecrübe süreleri

\begin{tabular}{|l|c|c|c|c|}
\hline $\begin{array}{l}\text { Yanıt } \\
\text { Seçenekleri }\end{array}$ & $\begin{array}{c}\text { Yanıtlar } \\
(\%)\end{array}$ & $\begin{array}{c}\text { Tecrübe } \\
\mathbf{( \% )} \\
\mathbf{( 0 - 5 )} \\
\text { Yıl }\end{array}$ & $\begin{array}{c}\text { Tecrübe } \\
\mathbf{( \% )} \\
\mathbf{( 6 - 1 0 )} \\
\text { Yll }\end{array}$ & $\begin{array}{c}\text { Tecrübe } \\
\mathbf{( \% )} \\
\mathbf{( 1 1 + )} \\
\text { Yıl }\end{array}$ \\
\hline $\begin{array}{l}\text { İnşaat } \\
\text { Mühendisliği }\end{array}$ & $81 \%$ & $25 \%$ & $28 \%$ & $6 \%$ \\
\hline Mimarlık & $19 \%$ & $13 \%$ & $6 \%$ & $3 \%$ \\
\hline TOPLAM & $100 \%$ & $38 \%$ & $34 \%$ & $9 \%$ \\
\hline
\end{tabular}

Şantiye şefi olarak görev yapan katılımcıların mesleki dağılımları ve tecrübe süreleri Çizelge 1 'de verilmiştir. Katılımcıların \%81'i inşaat mühendisi, \%19'u ise mimardır. İnşaat mühendislerinin \%25'i 0-5 y1l, \%28'i 6-10 y1l, $\% 6$ 'sı da 11 yıl ve üzeri tecrübeye sahiptir. Şantiye Şefi olarak çalışan mimarların ise \%13'ü 0-5 y1l, \%6'sı 6-10 yıl, \%3'ü de 11 yıl ve üzeri tecrübeye sahip oldukları çizelgeden görülmektedir.

Soru-2) Şantiye Şefleri İş Sağlığı ve Güvenliği Uzmanlığı Sertifikası almalı mıdır? Neden?

Çizelge 2. İSG uzmanlık sertifikası hakkındaki fikirler

\begin{tabular}{|l|c|c|}
\hline $\begin{array}{l}\text { Yanıt } \\
\text { Seçenekleri }\end{array}$ & $\begin{array}{c}\text { Yanıtlar } \\
\mathbf{( \% )}\end{array}$ & $\begin{array}{c}\text { Yanıtlar } \\
\text { (Kişi } \\
\text { Sayısı) }\end{array}$ \\
\hline Evet, almalıdır. & $78 \%$ & 25 \\
\hline Hayır, almamalıdır. & $22 \%$ & 7 \\
\hline TOPLAM & $100 \%$ & 32 \\
\hline
\end{tabular}

Çizelge 2'den görüldüğü üzere Şantiye Şeflerinin İSG Uzmanlığı Sertifikası; "Alınmalıdır" diyen katılımcıların oranı \%78 iken, "Alınmamalıdır" diyen katılımcıların oranı \%22'dir. Aşağıda yer alan katılımcı yorumlarından da anlaşıldığı üzere; \%78'lik kesim İş Sağlığı ve Güvenliği konusunun Şantiye Şefi uhdesinde olması nedeniyle ISG Uzmanlığı Sertifikasının Şantiye Şefleri tarafından alınması gerektiğini savunurken, \%22'lik kesim ise Şantiye Şeflerinin hâlihazırda yeteri derecede sorumluluğu bulunması nedeniyle şantiyelerde tek işi İSG olan sertifikalı uzmanların çalıştırılması gerektiğini savunmaktadır. 

"Neden" sorusuna "Olumlu" yanit verenlerin
yorumlarl:

- Çalışma planı yapılırken İş Sağlığı ve Güvenliği konusuna da dikkat edilmelidir.

- Almalıdır, çünkü bu konudaki tüm sorumluluk şantiye şeflerindedir.

- Almalıdır, ancak sertifika programının mevcut bedellerle olmaması lazım.

- Ayrıca da İSG uzmanı görevlendirilebilir.

- Her işte uzman olmak gerekir.

- Bilgi sahibi olduğunu göstermek için alınmalıdır.

- Şantiye şefliği kanunen işçi sağlığından da sorumlu bir unvandır. Bu konuda eğitimli olmalidir.

- İmalat sürecini bilmenin yanı sıra iş güvenliğine de hakim olmalıdır.

- Herhangi bir iş kazasında, başı büyük belaya gireceğinden önlemlerini almak zorundadır.

- Şantiye sahasında yapılan işlerden birebir sorumlu ve yetkili olması nedeniyle bu sertifika işlerin doğru yürümesi açısından çok faydalı olacaktır.

- Olası bir iș kazası durumunda ilk sorumlu kiși olarak şantiye şefi görüldügünden, gerekli ve alınması gereken iş güvenliği tedbirlerini bir iş güvenliği uzmanına bağlı kalmadan bilmesi gerekir. Aynı zamanda bu iş güvenliği ve işçi sağlığını kontrol mekanizmasını güçlendirir.

\section{"Neden” sorusuna “Olumsuz” yanit verenlerin yorumlarl:}

- Almasindan ziyade bu konudaki hukuki sorumluluğu bilmelidir.

- Çünkü yeterince teknik sorumluluğu mevcuttur. Bu konuyu başkası devralmalıdır.

- İş güvenliği ile ilgili iş ve işlemler şirket ile doğal bağlantısı olmayan bir kişi ve kurumca denetlenmeli ve iş güvenliği kurallarını denetleyecek kişide Çalışma ve Sosyal Güvenlik Bakanlığı tarafindan sertifika almış kişilerden atanmalı, Şantiye şefinin bu konudaki sorumlulukları da kaldırılarak denetleme görevi sadece bu kişi veya kurumlarda olmalıdır. Ücreti, vergi oranında bir indirim yapılarak işveren ve devlet tarafindan karşılanmalıdır. Böylece kaliteli bir hizmet verilebilir.

- Şantiyede her birey iş güvenliğinden sorumludur.

- Ayrica İSG uzmanı bulunmalıdır.
Soru-3)İş Sağlığı ve Güvenliği Sertifikasına sahip misiniz? Neden?

Çizelge 3. İSG sertifikasına sahip olma oranı

\begin{tabular}{|l|c|c|}
\hline $\begin{array}{l}\text { Yanıt } \\
\text { Seçenekleri }\end{array}$ & $\begin{array}{c}\text { Yanıtlar } \\
\mathbf{( \% )}\end{array}$ & $\begin{array}{c}\text { Yanıtlar } \\
\text { (Kişi } \\
\text { Sayısı) }\end{array}$ \\
\hline Evet, sahibim. & $12 \%$ & 4 \\
\hline Hayır, sahip değilim. & $88 \%$ & 28 \\
\hline TOPLAM & $100 \%$ & 32 \\
\hline
\end{tabular}

İş Sağlığı ve Güvenliği Sertifikasına sahipliğinin sorulduğu soruya; katılımciların \%12'si olumlu, $\% 88$ 'i ise olumsuz yanıt vermiştir. \%88'lik orana sahip katılımciların genel olarak; uzun ders saatlerine katılım sağlayacak vakitlerinin olmaması, yürüklükte olan mevzuatta Şantiye Şeflerinin İSG Uzmanlık Sertifikası almasına dair bir zorunluluk olmaması ve de yüksek kurs katılım ücretlerinden şikâyetçi oldukları, aşağıda yer alan yorumlardan anlaşılmaktadır.

"Neden” sorusuna “Olumlu” yanit verenlerin yorumlarl:

- Yönetici pozisyonunda olsanız bile yeterlilik sertifika programlarına katılımınız zorunlu olmalidir.

"Neden" sorusuna "Olumsuz" yanit verenlerin yorumlarl:

- Herhangi bir zorunluluk olmadığından sertifika almayı gerekli görmedim.

- Neden sınav için kurs mecburiyeti olduğunu anlayamiyorum.

- Uzun ders saatleri var ve katılım zorunlu, yeterli vakit ayıramıyorum.

- Eğitim ücreti olan 2000 TL'yi vermem zor.

- Başvuru yapmadim.

- İhtiyaç duymadım.

- Sorumlu bir vatandaş olarak risklerin farkındayım. Kendi uzmanı olduğum konuyla beraber hakkıyla yapamayacağımı düşünüyorum. Ayrıca ilgimi çekmiyor.

- Kamu çalışanıyım.

- Zaman ayıramadim.

- Çalışma dönemimde almak için firsatım olmadı ancak ilk uygun firsatta almak isterim. Ek olarak 
yurtdışındaki çalışmalarımda yabancı kontrollük tarafından verilen eğitim programlarına katılmıştım.

- Henüz almadım. Şu anda Çalışma ve Sosyal Güvenlik Bakanlığı inşaatlar için gerekli olan düzeyde iş güvenliği uzmanı sertifikası verimini durdurdu.

Soru-4) Çalıştığınız şantiyede İş Sağlığı ve Güvenliğiyle ilgili alınan önlemlerin yeterli olduğunu düşünüyor musunuz?

Çizelge 4. İSG önlemlerinin yeterliliği hakkındaki fikirler

\begin{tabular}{|l|c|c|}
\hline $\begin{array}{l}\text { Yanıt } \\
\text { Seçenekleri }\end{array}$ & $\begin{array}{c}\text { Yanıtlar } \\
\text { (\%) }\end{array}$ & $\begin{array}{c}\text { Yanıtlar } \\
\text { (Kişi ) }\end{array}$ \\
\hline Evet, düşünüyorum. & $34 \%$ & 11 \\
\hline Hayır, düşünmüyorum. & $66 \%$ & 21 \\
\hline TOPLAM & $100 \%$ & 32 \\
\hline
\end{tabular}

İş Sağlığı ve Güvenliğiyle ilgili çalıştıkları şantiyede alınan önlemlerin yeterliliğinin sorulduğu soruya katılımcıların \%34'ü yeterli önlem alındığını belirtirken, \%66'sı aksi yönde görüş bildirmiştir.

Soru-5) Çalıştığınız şantiyede İş Sağlığı ve Güvenliği ile ilgili eksiklik ve kusurları, öneri ve önlemleri belirleyerek, yapı müteahhidine rapor ediyor ve şantiyede görev alan ilgili kişilere bildiriyor musunuz?

Çizelge 5. İSG ile ilgili eksiklik ve kusurları bildirenlerin oranı

\begin{tabular}{|l|c|c|}
\hline $\begin{array}{l}\text { Yanıt } \\
\text { Seçenekleri }\end{array}$ & $\begin{array}{c}\text { Yanıtlar } \\
(\%)\end{array}$ & $\begin{array}{c}\text { Yanıtlar } \\
\text { (Kişi } \\
\text { Sayısı) }\end{array}$ \\
\hline Evet, bildiriyorum. & $75 \%$ & 24 \\
\hline Hayır, bildirmiyorum. & $25 \%$ & 8 \\
\hline TOPLAM & $100 \%$ & 32 \\
\hline
\end{tabular}

İş Sağlığı ve Güvenliği ile ilgili eksiklik ve kusurları, öneri ve önlemleri belirleyerek, yap1 müteahhidine rapor edip şantiyede görev alan ilgili kişilere bildirilip bildirilmediğinin sorulduğu soruya; katılımcıların \%75'i bildirdikleri, \%25'i ise bildirmedikleri yönünde cevap vermişlerdir.

Soru-6) Çalıştığınız şantiyede, inşaat ve tesisat işlerinde yetki belgesi olmayan usta çalıştırıyor musunuz? Neden?

Çizelge 6. İnşaat işlerinde yetki belgesi olmayan usta çalıştıranların oranı

\begin{tabular}{|l|c|c|}
\hline $\begin{array}{l}\text { Yanıt } \\
\text { Seçenekleri }\end{array}$ & $\begin{array}{c}\text { Yanıtlar } \\
\mathbf{( \% )}\end{array}$ & $\begin{array}{c}\text { Yanıtlar } \\
\text { (Kişi } \\
\text { Sayısı) }\end{array}$ \\
\hline Evet, çalıştırıyorum. & $62 \%$ & 20 \\
\hline Hayır, çalıştırmıyorum. & $38 \%$ & 12 \\
\hline TOPLAM & $100 \%$ & 32 \\
\hline
\end{tabular}

Çalışılan şantiyede, inşaat ve tesisat işlerinde yetki belgesi olmayan usta çalıştırılıp çalıştırılmadığının sorulduğu soruya; katılımciların \%62'si çalıştırdıkları, \%38'i ise çalıştırmadıkları yönünde cevap vermişlerdir. Aşağıda yer alan yorumlar incelendiğinde; yetki belgeli usta sayısının az olduğu, deneyimli yetki belgesiz ustanın deneyimsiz yetki belgeli ustaya şantiye ortamında tercih edildiği ve yetki belgeli ustaların daha yüksek ücretle çalışmaları, \%62'lik kesimin nedenleri olarak görülebilir.

"Neden" sorusuna “Olumlu” yanit verenlerin yorumlart:

- İşlerin daha profesyonel olması için yetki belgeli usta tercih ediyorum.

"Neden" sorusuna "Olumsuz" yanit verenlerin yorumlarl:

- Maalesef patron ne derse oluyor.

- Çünkü yetki belgesi olan usta sayısı son derece yetersiz.

- Maalesef patron ne derse o oluyor, parayı veren maalesef düdüğü çalıyor.

- Yetki belgesi olması uzman olduğu anlamına gelmiyor ne yazık ki.

- Bu konu henüz tam olarak tabana yayılmamıştır.

- Yetki belgesi alan kişiler normal piyasa fiyatının çok üzerinde ücret talep ediyor bu sebeple benim için önemli olan işin sıhhatli yapılmasıdır.

- Sertifika almış usta azlığı. 
• Görev ve sorumluluklar yeterlilikler ölçüsünde belirlenmelidir.

- Sektörde çok fazla sertifikalı usta bulunmuyor.

- Yetki belgeli taşeron yok.

- Yetki belgesi sahibi ustaların yaygın olmaması.

- Zaman zaman çalıştırmak durumunda kalınabiliyor çünkü ülkemizde bu konu henüz yeterince yaygın değil. $\mathrm{Bu}$ nedenle tüm çalışanlarda bu sertifika bulunamayabiliyor.

- Deneyim, tecrübe ve işçilik sertifikadan daha önce geliyor.

Soru-7) Çalıştığınız şantiyede yapılacak imalatı yap1 denetim kuruluşuna ne zaman haber veriyorsunuz?

Çizelge 7. Yapılacak imalatı yapı denetim kuruluşuna haber verme zamanları

\begin{tabular}{|l|c|c|}
\hline $\begin{array}{l}\text { Yanıt } \\
\text { Seçenekleri }\end{array}$ & $\begin{array}{c}\text { Yanıtlar } \\
(\%)\end{array}$ & $\begin{array}{c}\text { Yanıtlar } \\
\text { (Kişi } \\
\text { Sayısı) }\end{array}$ \\
\hline En az 1 gün önce & $62 \%$ & 20 \\
\hline $\begin{array}{l}\text { İmalat yapılmaya } \\
\text { başlanınca }\end{array}$ & $31 \%$ & 10 \\
\hline $\begin{array}{l}\text { İmalat yapıldıktan } \\
\text { sonra }\end{array}$ & $6 \%$ & 2 \\
\hline Bildirmiyorum & $6 \%$ & 2 \\
\hline TOPLAM & & 34 \\
\hline
\end{tabular}

Çalışılan şantiyede yapılacak imalatın yapı denetim kuruluşuna ne zaman haber verildiğinin sorulduğu soruya; katılımcıların yalnızca \%62'si mevzuata ve işin doğasına uygun olan cevabı vermiştir. Geriye kalan \%37'lik kesim ise üzerlerine aldıkları görevin sorumluluğunun gereğini yerine getirmemektedirler.

Soru-8) İnşaat ruhsatı almamış yapılarda şantiye şefi olarak çalışmak sizin açınızdan bir sorun teşkil eder mi? Neden?
Çizelge 8. İnşaat ruhsatı almamış yapılarda şantiye şefi olarak çalışabileceklerin oranı

\begin{tabular}{|l|c|c|}
\hline $\begin{array}{l}\text { Yanıt } \\
\text { Seçenekleri }\end{array}$ & $\begin{array}{c}\text { Yanıtlar } \\
(\%)\end{array}$ & $\begin{array}{c}\text { Yanıtlar } \\
\text { (Kişi } \\
\text { Sayısı) }\end{array}$ \\
\hline $\begin{array}{l}\text { Evet, sorun teşkil } \\
\text { eder. }\end{array}$ & $75 \%$ & 24 \\
\hline $\begin{array}{l}\text { Hayır, sorun teşkil } \\
\text { etmez. }\end{array}$ & $19 \%$ & 6 \\
\hline TOPLAM & $94 \%$ & 30 \\
\hline
\end{tabular}

İnşaat ruhsatı almamış yapılarda şantiye şefi olarak çalışmanın problem olup olmayacağının sorulduğu soruya; katılımcıların \%75'i sorun olacağı, \%19'u sorun olmayacağı şeklinde cevap vermiştir. Anketimiz katılımcilarının \%6's1 ise bu soruyu yanıtlamamıştır.\%75 orana sahip kesimin genel olarak, ruhsatsız yapıların; kanunen sıkıntılı olması, her türlü mevzuata aykırılığı nedeniyle riskli ve tehlikelibir durum olduğunu belirttiklerini, aşağıda yer alan yorumlardan görebiliriz.

"Neden” sorusuna “Olumlu” yanit verenlerin yorumlarl:

- Resmiyete binmemiş işler sorun yaratabilir.

- Ruhsatı alınmamış bir yapıya teknik hizmet desteği verilmesini doğru bulmuyorum. Zaten süreç yasallaşmamış henüz.

- Ruhsatsız yapı ve burada oluşacak iş kazaları büyük suç statüsüne girmektedir.

- Mevzuat açısından birçok sorun oluşturması muhtemeldir.

- Yasal prosedürleri yerine getirilmemiş hiçbir iş yerinde resmi olarak hak talebiniz olamaz.

- Kanunen yasaktır.

- İmar mevzuatına uymayan bir yapı kaçak yapı demektir.

- Her an tehlikeli bir durum olabilir.

- Ruhsatsız bir binada çalışmak hem kanuni hem de meslek etiği açısından yanlış olduğunu düşünüyorum

- Ruhsatsız inşaatlarda çalışarak daha büyük risk ve sorumluluk altına girmek istemem.

- Sıkıntılı bir durum, başka seçenekler varken ruhsatsız yerde çalışmam ama zorunda kalırsam mecburen çalışabilirim. 
"Neden” sorusuna "Olumsuz" yanit verenlerin yorumlarl:

- Ruhsat müteahhidin problemidir.

Soru-9) Şantiye şefi olarak görev aldığınız bir yapının inşaatının bitiminde iskân izni alınmaması sizin açınızdan problem teşkil eder mi? Neden?

Çizelge 9. Yapının inşaatının bitiminde iskân izni almamasını sorun edeceklerin oranı

\begin{tabular}{|l|c|c|}
\hline $\begin{array}{l}\text { Yanıt } \\
\text { Seçenekleri }\end{array}$ & $\begin{array}{c}\text { Yanıtlar } \\
\mathbf{( \% )}\end{array}$ & $\begin{array}{c}\text { Yanıtlar } \\
\text { (Kişi } \\
\text { Sayısı) }\end{array}$ \\
\hline $\begin{array}{l}\text { Evet, problem teşkil } \\
\text { eder. }\end{array}$ & $59 \%$ & 19 \\
\hline $\begin{array}{l}\text { Hayır, problem teşkil } \\
\text { etmez. }\end{array}$ & $34 \%$ & 11 \\
\hline \begin{tabular}{l} 
TOPLAM \\
\hline
\end{tabular} & $93 \%$ & 30 \\
\hline
\end{tabular}

Şantiye şefi olarak görev alınan yapının inşaatının bitiminde iskân izni alınmamasının problem teşkil etme hususunun sorulduğu soruya; katılımciların \%59'u problem teşkil edeceği yönünde, \%34'ü ise aksi yönde görüş bildirmiştir.Anketimiz katılımcilarının \%7'si ise bu soruyu yanıtlamamıştır. \%59 orana sahip kesimin genel olarak; iskân izninin alınmaması sonucu sorumluluğun devam edeceğini ve de eksik kalan/yapılmayan bir iş nedeniyle iskân izninin alınamamasının itibar kaybına yol açacağı, şeklinde yaptıkları yorumları aşağıdaki başlıklar altında görebiliriz.

"Neden" sorusuna "Olumlu” yanit verenlerin yorumlarl:

- Yapı kullanma izninin alınmaması o şantiyedeki sorumluluğun devamı anlamına geldiği için önemlidir.

- İş bitirme için sorun teşkil edebilir.

- Boşa harcanan para ve itibar kaybıdır.

- Tamamlanmış olan her tür yapının bulunduğu ülke şartlarında resmi olarak teslim edilmesi ve işletime alınması ileride oluşabilecek hak mağduriyetlerini ortadan kaldıracaktır.

- İskân izni alınmadıkça iş bitmiş sayılmaz. Sorumluluk devam eder.

- İskân izni alınmaması bir eksikliğin ifadesidir.

- Yapılan işin sonucunda tasdik edilmemesi anlamına geleceği için rahatsız olurum.

"Neden" sorusuna "Olumsuz" yanit verenlerin yorumlarl:

- İskân da müteahhidin problemidir.

- O müteahhidin problemi, beni ilgilendirmez.

- Ben işin tekniğine bakarım.

- İnşaat kazasız belasız bitmiştir.

- İskân alınmaması durumunun benden, şantiye yönetimimden kaynaklı olmadığını bilirim.

Soru-10) Yapım işlerindeki kusurlardan dolayı yap1 sahibi ve yüklenici arasında gelecekte oluşabilecek problemlerden etkilenebileceğinizi düşünüyor musunuz? Neden?

Çizelge 10. Yapımdaki kusurlar nedeniyle yapı sahibi ve yüklenici arasındaki sorunlardan etkilenebileceklerin oran 1

\begin{tabular}{|l|c|c|}
\hline Yanıt & $\begin{array}{c}\text { Yanıtlar } \\
(\%)\end{array}$ & $\begin{array}{c}\text { Yanıtlar } \\
\text { (Kişi } \\
\text { Sayısı) }\end{array}$ \\
\hline $\begin{array}{l}\text { Evet, etkilenebileceğimi } \\
\text { düşünüyorum. }\end{array}$ & $63 \%$ & 20 \\
\hline $\begin{array}{l}\text { Hayır, } \\
\text { etkilenebileceğimi } \\
\text { düşünmüyorum. }\end{array}$ & $31 \%$ & 10 \\
\hline TOPLAM & $94 \%$ & 30 \\
\hline
\end{tabular}

Yapım işlerindeki kusurlardan dolayı yapı sahibi ve yüklenici arasında gelecekte oluşabilecek problemlerden etkilenebileceğini düşünenlerin sorulduğu soruya; katılımcıların \%63'ü etkilenebileceğimi düşünüyorum şeklinde yanıt verirken \%31'i aksi yönde cevap vermiştir. Anketimiz katılımcılarının \%6'sı ise bu soruyu olumlu veya olumsuz bir şekilde yanıtlamamıştır. \%63 orana sahip kesimin genel olarak; şantiyedeki tüm sorumluluğun şantiye şefinde olduğunu 
belirttiklerini, aşağıda yer alan yorumlardan görebiliriz.

\section{"Neden” sorusuna “Olumlu” yanıt verenlerin yorumlarl:}

- Şantiye şefi olarak yapının tüm alanlarında sorumlu bulunmamdan dolayı herhangi bir kusurdan etkilenebileceğimi düşünüyorum.

- Tabii ki öncelikle yüklenici, şantiye şefim sorumluydu diyecektir. $\mathrm{Bu}$ konuda yasal düzenlemeler uygulama aşamasında ya bilinmiyor ya da es geçiliyor. Bu konuda denetim ve yetki sınırının inşaat mühendislerine sürekli eğitimlerle verilmesi gerektiğini düşünüyorum.

- Yasal ve manevi olarak kariyerimde etik olmayan ya da kusurlu sayilabilecek unsurların olmasinı kabul edemem.

- Şantiye şefi işlerin fen ve sanat kurallarına uygun yapilmasindan sorumludur.

- Şantiye şefi olarak her türlü sorumluluğu üstleniyorsun. $\mathrm{Bu}$ durum da gelecekte başını ağritabilir.

"Neden" sorusuna “Olumsuz” yanit verenlerin yorumlarl:

- Etkilenmem, beni ilgilendiren bir konu değil.

- Binanın taşıyıcı konstrüksiyonu hariç ve sorun kendi hatamdan değilse diğer imalatlar işverenin parasal gücüne ve kaliteli malzeme ve işçilik kullanmasına bağlı olduğundan etkileneceğimi düşünmüyorum

- Ben kendi işime bakarım.

- Herkes elini taşın altına koymalıdır.

- İşimi doğru yaptığımı düşünürüm.

- Yapı işlerinde ileride kusur çıkarabilecek imalat yaptırmam. Yapının yönetimi bendeyse eğer, gerekeni müteahhide rağmen yaparım. Gerekeni yapamayacağım kişilerle çalışmam.

\section{TARTIŞMA VE SONUÇLAR}

Çalışma kapsamında şantiye şeflerinin yetki ve sorumlulukları hakkındaki farkındalık düzeyi bir anket çalışması ile belirlenmeye çalışılmış ve aşağıdaki sonuçlar elde edilmiştir. Şantiye şefleri çoğunluğu;

(1) Kendi sorumluluklarını belirleyen mevzuattan habersizlerdir. Bir kısmı ise mevzuatla ilgili bilinçli olduğu halde gereğini yapmamaktadırlar.

(2) İSG sertifikası alınması gerektiğini düşünmekle birlikte İSG sertifikasına sahip değillerdir.

(3) 01.01.2020 tarihine kadar iş güvenliği uzmanlığı belgesi almaları gerektiğinden haberdar değillerdir.

(4) Çalıştıkları şantiyede, iş sağlığı ve güvenliğiyle ilgili yeterli önlem alınmadığını düşünmektedirler. Buna rağmen iş sağlığı ve güvenliği ile ilgili eksiklik ve kusurları, öneri ve önlemleri belirleyerek, yap1 müteahhidine rapor etmektedirler.

(5) Görev aldıkları şantiyede inşaat ve tesisat işlerinde yetki belgesi olmayan ustaları çalıştırmaktadırlar.

(6) İnşaat ruhsatı almamış yapılarda şantiye şefi olarak çalışmanın problem olacağını düşünmektedirler. Fakat bu konuda yeterli hukuki altyapıya sahip olmadıkları yaptıkları yorumlardan anlaşılmaktadır.

(7) Yapım işlerindeki kusurlardan dolayı yapı sahibi ve yüklenici arasında gelecekte oluşabilecek problemlerden etkileneceklerini düşünmektedirler. Fakat aralarında yapının iskân izni alınmamasının kendileri açısından problem teşkil etmeyeceğini düşünenler de bulunmaktadır.

Araştırma sonucunda; şantiye şeflerinin ilgili mevzuatlardan habersiz, büyük oranda aldıkları sorumluluğun ciddiyetini bilmeden iş yükü altına girdikleri anlaşılmış ve yaptıkları görevin sorumlulukları hakkında ciddi eksikliklerinin olduğu ortaya çıkmıştır. $\mathrm{Bu}$ eksiklerin giderilebilmesi, öncelikle ilgili mevzuatların şantiye şefleri tarafindan öğrenilmesi ile mümkün olacaktır. $\mathrm{Bu}$ amaçla şantiye şeflerine yönelik eğitimlerin Meslek Odaları, Üniversiteler vb. kurumlar tarafindan zorunlu tutulması ve de takibinin sağlanması gerektiği düşünülmektedir.

\section{KAYNAKLAR}

1. Yap1 Müteahhitlerinin Kayıtları ile Şantiye Şefleri ve Yetki Belgeli Ustalar Hakkında Yönetmelik (2010). T.C. Resmi Gazete, 27787, 16 Aralık 2010. 
2. Yapı Denetimi Uygulama Yönetmeliği. (2008). T.C. Resmi Gazete, 26778, 5 Şubat 2008.

3. Çevre ve Şehircilik Bakanlığı 2013/24 no'lu Genelgesi, 2013. 6581 Sayı, 1 Ağustos 2013.

4. İmar Kanunu ile Bayındırlık ve İskân Bakanlığının Teşkilat ve Görevleri Hakkında Kanun Hükmünde Kararnamede Değişiklik Yapılmasina Dair Kanun. (2009). T.C. Resmi Gazete, 5940, 9 Aralık 2009.

5. 6331 sayılı İs Sağlığı ve Güvenliği Kanunu. 2012. T.C. Resmi Gazete, 28339, 30 Haziran 2012.

6. 4708 sayıl1 Yapı Denetim Kanunu, 2001. T.C. Resmi Gazete, 4708, 29 Haziran 2001.

7. Türk Ceza Kanunu., 2004. T.C. Resmi Gazete, 25611, 12 Ekim 2004. 